\title{
Cohesive fracture in composite systems: experimental setup and first results
}

\author{
Valentino Paolo Berardi \\ Department of Civil Engineering, University of Salerno, Via Giovanni Paolo II 132, Fisciano (SA), Italy \\ berardi@unisa.it \\ Michele Perrella, Gabriele Cricrì \\ Department of Industrial Engineering, University of Salerno, Via Giovanni Paolo II 132, Fisciano (SA), Italy \\ mperrella@unisa.it,gcricri@unisa.it
}

\begin{abstract}
Composite systems are widely used in many engineering applications for new structures and strengthening of existing ones. Within the structural rehabilitation of civil constructions, the plating technique of beams with Fiber Reinforced Polymer (FRP) represents a quick and optimal intervention with respect to traditional ones. The failure of these composite systems usually occurs due to the FRP debonding, which corresponds to a mode II fracture of concrete specimens. In this paper, a new experimental setup for investigating the mode II fracture behavior of FRP-concrete composite structures is presented. The test equipment consists of both conventional equipment and a non-contact optical technique, Digital Image Correlation (DIC), and the test system was realized at the Design Machine Laboratory of the University of Salerno. A preliminary test was performed and the corresponding results are shown and discussed.
\end{abstract}

KEYwORDs. Composite systems; Fiber Reinforced Polymer (FRP); Debonding; Mechanical testing; Digital Image Correlation (DIC).

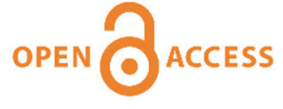

Citation: Berardi, V. P., Perrella, M., Cricrì, G., Cohesive fracture in composite systems: experimental setup and first results, Frattura ed Integrità Strutturale, 48 (2019) 222-229.

Received: 11.12 .2018

Accepted: 09.01.2019

Published: 01.04.2019

Copyright: (C) 2019 This is an open access article under the terms of the CC-BY 4.0, which permits unrestricted use, distribution, and reproduction in any medium, provided the original author and source are credited.

\section{INTRODUCTION}

A dhesive junctions have become widely adopted for structural applications in many engineering fields, typically for realizing industrial, automotive, naval and aerospace high-tech structural elements [1,2], as well as for rehabilitating existing civil structures (reinforced concrete and masonry structures) with external Fiber Reinforced Polymer (FRP) reinforcements [3-12].

Within the field of Civil Engineering, the design of strengthening by bonding composite plates and sheets requires the evaluation of brittle and ductile failure modes, in order to achieve a controlled overall ductile behavior of the structure. Typical brittle failure modes are associated with debonding close to either FRP cut-off cross sections (end debonding) or 
flexural cracks (intermediate debonding). According to the capacity design criteria, failure due to brittle debonding phenomena shall not forego flexural or shear failure of the strengthened member.

In common applications, the end debonding generally represents the design condition and a maximum value of composite stress (lower than composite strength) is associated with it.

No specific standards are available to experimentally evaluate the FRP maximum stress corresponding to end debonding. Some technical recommendations are provided in the American ACI 440.2R-08 [13], the European fib T.G. 9.3 [14] and the Italian CNR-DT 200 R1/2013 [15] guidelines to predict such design FRP stress by means of semi-empirical formulae. Within this context, some specific aspects of this technique have yet to be studied in deeper detail.

With reference to FRP-concrete end debonding, it is well-known that the corresponding mechanical behavior can be modeled via a cohesive law, that allows also the prediction of the mode II fracture mechanism experimentally observed in failure of strengthened systems [16-20].

Several researchers are being studied this local failure mechanism by proposing different test setups, generally based on either linear variable displacement transducers (LVDTs) or laser meter devices installed on composite plate and located at the beginning of bonded area, as well as on strain gauges, positioned along longitudinal direction [21-23].

Some recent studies have introduced a non-contact optical technique, digital image correlation (DIC), to obtain the FRPconcrete slip on extended areas of tested specimen rather than only on the beginning of bonded area [24-32]. This promising method also allows for an estimation, with a good accuracy, of the strain field on FRP and concrete core external surfaces. Within this context, a new experimental setup for the identification of cohesive law at the adhesive interface of strengthened systems is presented. It is based on a mechanical anchorage system of specimen and DIC outcomes, without requiring any strain gauges and LVDTs/laser meter records.

An optimized DIC procedure is proposed, consisting of a data processing limited to selected regions of interest (ROI), in order to drastically reduce the computational burden and point out experimental displacements in a more accurate way and overcoming the boundary effects of inhomogeneous zones.

Several experimental debonding tests on a concrete block externally plated with GFRP pultruded laminate have been performed for validation purposes at the Design Machine Laboratory of the University of Salerno.
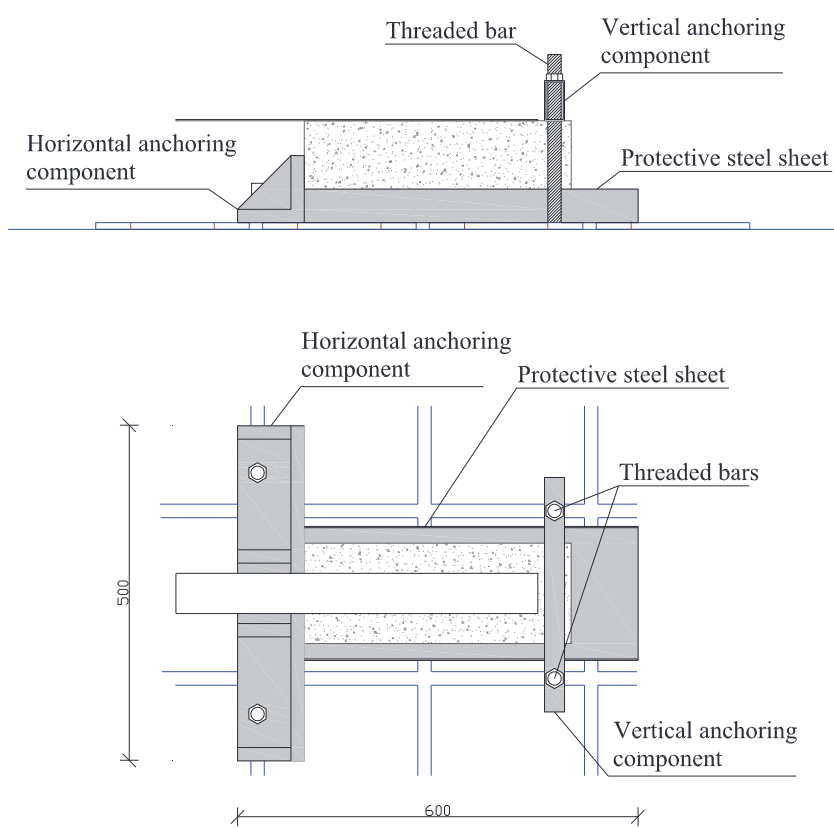

Figure 1: Anchoring device - lateral and top views (dimensions in $\mathrm{mm}$ ).

\section{MATERIALS AND METHODS}

he experimental setup was designed with the aim to achieve an effective anchoring of strengthened specimen and an optimal placement of camera.

It consists of: 
- $\quad$ a testing device to apply load;

- a data acquisition system.

A still anchoring device mounted on the laboratory modular basement was realized to fix the reinforced specimen (Fig. 1).

Load is applied using a $20-\mathrm{kN}$ servo-hydraulic actuator mounted on the laboratory modular basement (Fig. 2).

The data acquisition system includes:

- actuator load cell and LVDT;

- industrial 5 Mpixel camera;

- strain gauges bonded to external surface of the specimens;

- database management system.

The equipment can automatically record the data at fixed time steps.

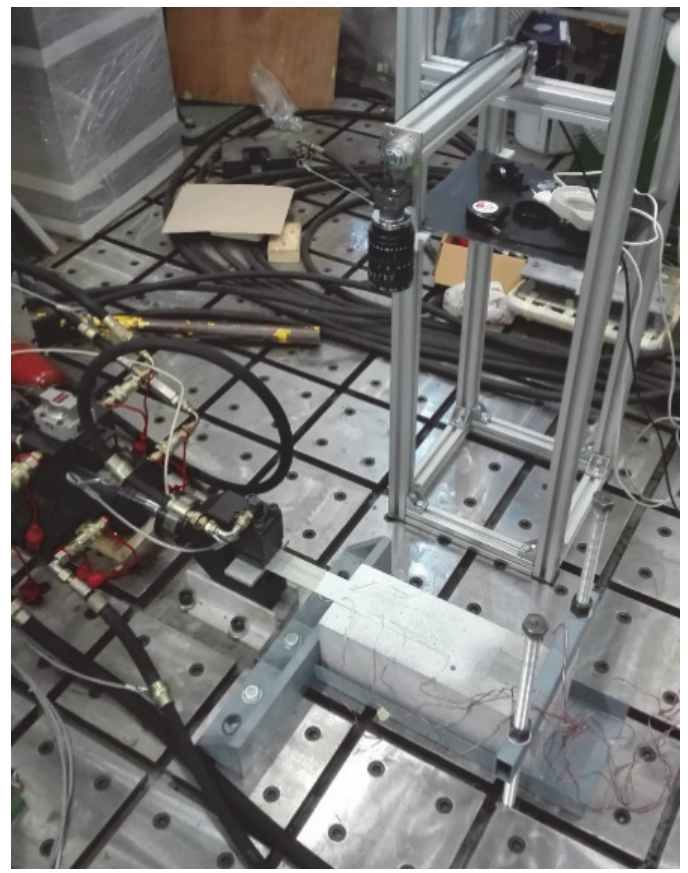

Figure 2: Testing Device.

A preliminary debonding test was performed on a concrete specimen reinforced with GFRP composite laminate. The tested prismatic concrete block $\left(150 \times 150 \times 400 \mathrm{~mm}^{3}\right)$ is one of a series of specimens manufactured using low strength concrete to best simulate the interface behavior of strengthened existing structures. Composite reinforcement was made of a pultruded E glass/polyester fiber reinforced polymer with a thickness of $1.6 \mathrm{~mm}$. The E-glass fiber volume fraction was equal to $35 \%$. A two component epoxy resin was used for bonding. A controlled thickness of $1.6 \mathrm{~mm}$ was imposed to the adhesive layer. The specimens were cured at $30^{\circ} \mathrm{C}$ for 72 hours.

First, five cubic samples $\left(150 \times 150 \times 150 \mathrm{~mm}^{3}\right)$ made of the same concrete mixture of the prismatic specimens were prepared and tested, according to ISO 1920-4 standard, in order to evaluate the mean compressive strengths, respectively cubic $R_{c m}$ and cylindrical $f_{\mathrm{cm}}$. Second, tensile tests, according to ASTM D3039M standard, were performed to obtain the mean Young's modulus $E_{G F R P}$ and ultimate tensile stress $f_{G F R P}$ along fiber direction of the pultruded GFRP composite. The experimental mechanical properties of concrete and GFRP laminate, together with the nominal Young's modulus Er and tensile strength $f_{r}$ of resin, according to the manufacturer technical datasheet, are listed in Tab. 1.

\begin{tabular}{cccccc}
\hline $\begin{array}{c}R_{c m} \\
{[\mathrm{MPa}]}\end{array}$ & $\begin{array}{c}f_{c m} \\
{[\mathrm{MPa}]}\end{array}$ & $\begin{array}{c}E_{G F R P} \\
{[\mathrm{MPa}]}\end{array}$ & $\begin{array}{c}f_{G F R P} \\
{[\mathrm{MPa}]}\end{array}$ & $\begin{array}{c}E_{r} \\
{[\mathrm{MPa}]}\end{array}$ & $\begin{array}{c}f_{r} \\
{[\mathrm{MPa}]}\end{array}$ \\
24.54 & 20.37 & 48000 & 800 & 11200 & $25-30$ \\
\hline
\end{tabular}

Table 1: Mechanical properties of specimens' materials. 
The glued zone (hatched zone) and the strain gauges configuration are depicted in Figs. 3 and 4, respectively. The origin of loading $x$ axis corresponds to the top edge of the bonded area.

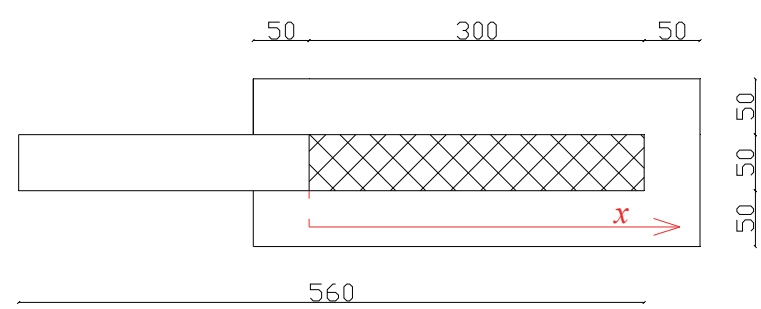

Figure 3: Details of the glued zone.

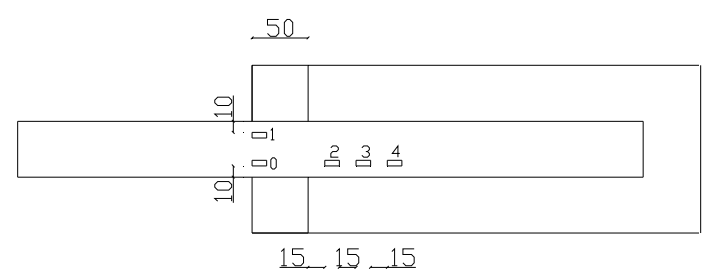

Figure 4: Strain gauges configuration.

The tests were performed under displacement control with a rate of $0.01 \mathrm{~mm} / \mathrm{s}$ until failure occurrence. The following experimental data were recorded during test execution:

- Digital video for image processing with DIC technique;

- Relative displacement between specimen edges by the test machine (LVDT);

- Load applied to composite laminate by the test machine load cell;

- Strains of composite and concrete, measured via strain gauges.

The DIC analysis was performed for the preliminary test (specimen \#1) by considering 25 small (2 mm diameter) circular regions of interest (ROI) as shown in Fig. 5.

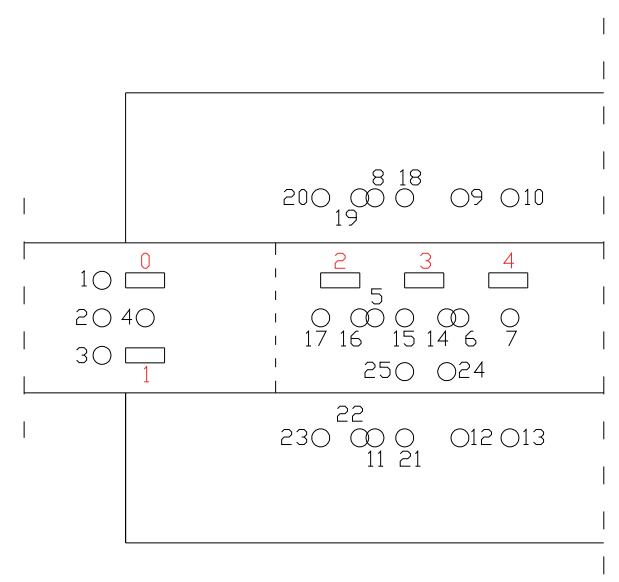

Figure 5: Details of ROIs.

The Ncorr algorithm [33], enhanced via an in house made Matlab routine, was used for DIC analysis. Such a routine allows to evaluate the resulting displacement vector for each ROI center by getting the mean value of the computed data in a ROI center neighborhood. Thus improving the displacement measurement accuracy. 


\section{RESULTS AND DISCUSSION}

he load-displacement curve, acquired by the testing machine during the preliminary debonding experiment (specimen \#1), is plotted in Fig. 6, exhibiting a typical trend as in literature. The maximum value of the applied force of about $13 \mathrm{kN}$ was recorded, whereas the maximum displacement ranged within $3 \mathrm{~mm}$. A typical debonding failure mode was observed (Fig. 7), corresponding to the optimal collapse mechanism of strengthened concrete due to the fact that the concrete shear strength is lower than for the adopted resin.

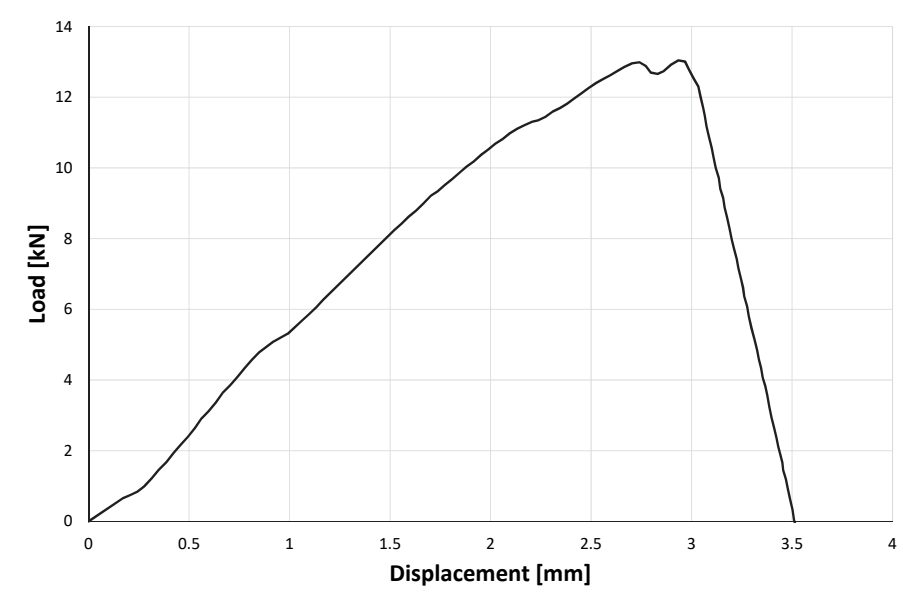

Figure 6: Load-displacement curve.

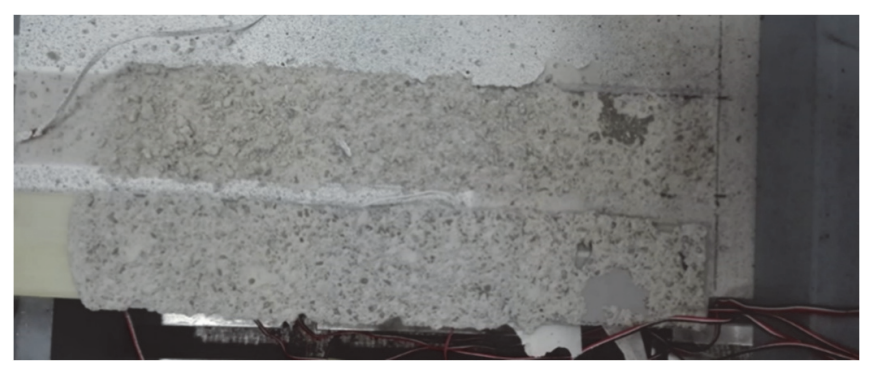

Figure 7: Debonding failure mode.

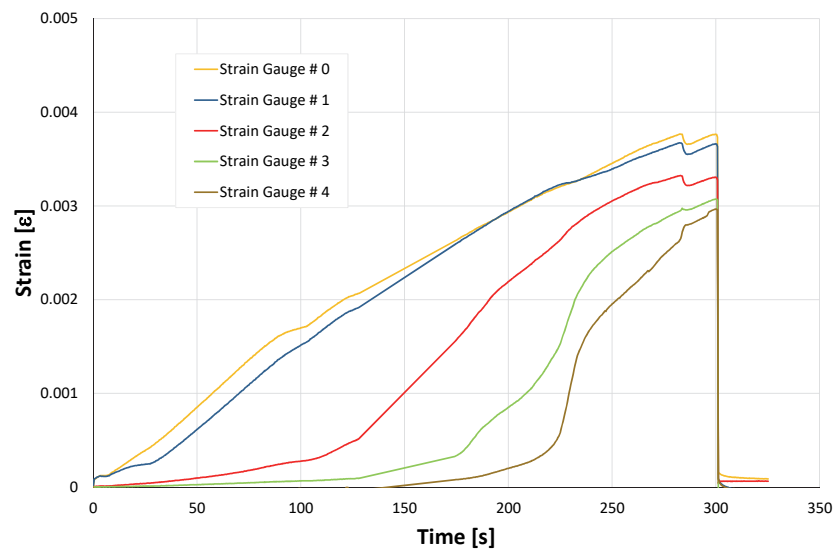

Figure 8: GFRP strain vs. time curves.

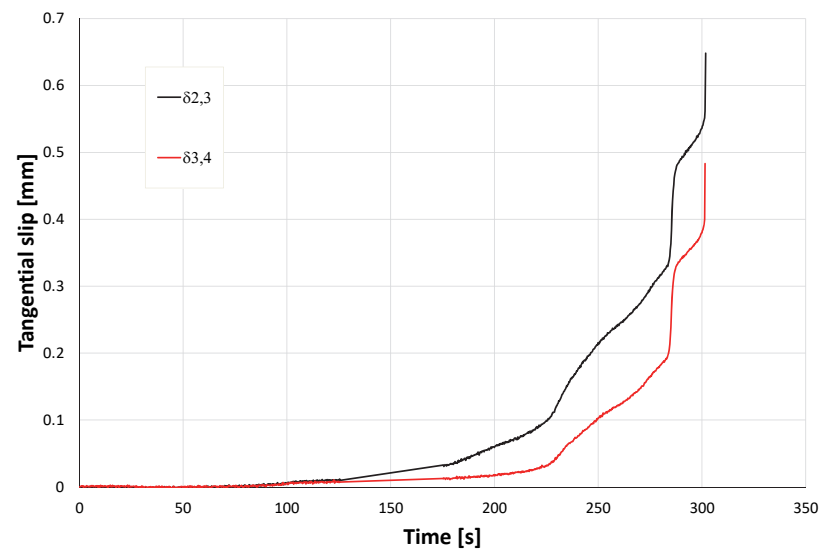

Figure 9: Tangential slip vs. time curves obtained by DIC technique.

The tangential slips $\delta_{i, i+1}$ evaluated by DIC technique, are considered as the relative displacement of mid points between the cross-sections corresponding to $\mathrm{i}$-th and (i+1)-th GFRP strain gauges. The GFRP strain $\varepsilon_{i}$ versus time curves and the tangential slip $\delta_{i, i+1}$ versus time curves are plotted in Figs. 8 and 9 respectively. The proposed methodology is capable of 
properly determining the slips over extended areas respect to punctual displacement evaluation provided by traditional LVDTs. In such a way, it is possible to model a more accurate adhesive interface behavior and to track the debonding propagation.

The strains provided by DIC technique, obtained by the displacements of $16^{\text {th }}-17^{\text {th }}$ ROIs, resulted in good agreement with those measured by the strain gage \#2, except for the final debonding stage, close to the failure occurrence (Fig. 10). This is probably due to the formation of out of plane displacements that affect the accuracy and effectiveness of bidimensional DIC technique.

The mean shear stresses at the adhesive interface, $\tau_{i, i+1}$, acting between the cross-sections corresponding to the $i$-th and (i+1)-th GFRP strain gauges, were evaluated by means of strains variation measured along the loading $x$ axis, according to the method proposed in literature [13-14]:

$$
\tau_{i, i+1}=-\frac{E_{G F R P} \cdot A_{G F R P} \cdot\left(\varepsilon_{i+1}-\varepsilon_{i}\right)}{B_{G F R P} \cdot\left(x_{i+1}-x_{i}\right)}
$$

being:

- $A_{G F R P}=t_{G F R P} \cdot B_{G F R P}$ the cross sectional area of the composite laminate;

- $\quad \mathrm{t}_{\mathrm{GFRP}}, \mathrm{B}_{\mathrm{GFRP}}$ and $\mathrm{E}_{\mathrm{GFRP}}$ the thickness, the width and the Young's modulus along the fiber direction of the composite laminate, respectively.

The shear stress vs. tangential slip curves are depicted in Fig. 11.

These curves are representative of experimental evaluations of cohesive shear acting at the concrete-GFRP interface in a form coherent with a Cohesive Zone (CZM) approach and with recent literature results [21-32].

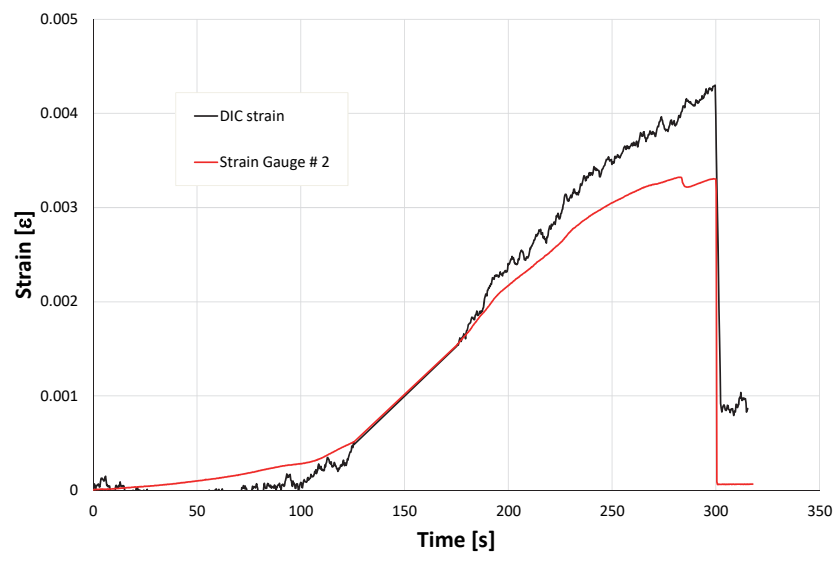

Figure 10: Strains vs. time curve by DIC.

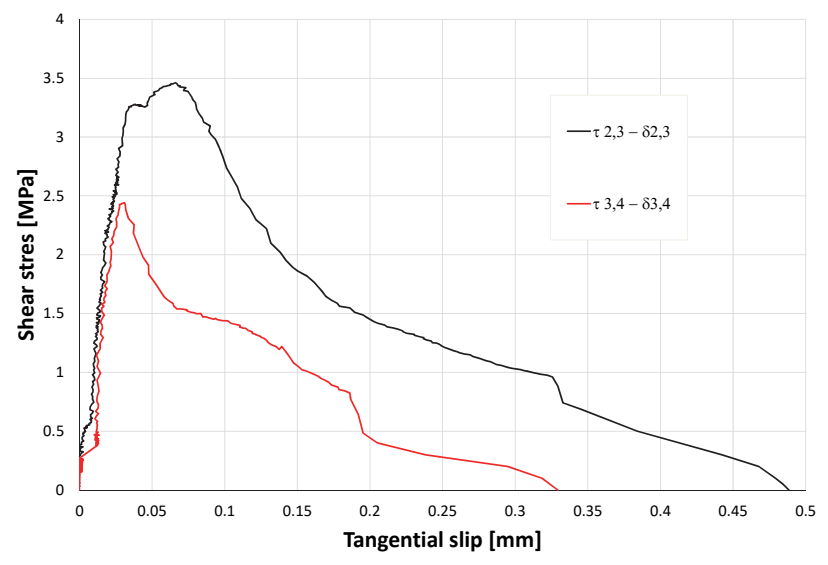

Figure 11: Shear stress vs. tangential slip curves.

The value of the observed debonding force falls within the range of experimental outcomes obtained by the authors through a previous testing system on similar specimens made of the same GFRP lamina and epoxy resin [18]. Moreover, further experimental tests were carried out in order to validate the proposed testing system. The outcomes, in terms of debonding force, are reported in Tab. 2, thus assessing the reproducibility of the results.

\begin{tabular}{ccccc}
\hline Specimen \# & $\begin{array}{c}\text { Debonding force } \\
{[\mathrm{kN}]}\end{array}$ & $\begin{array}{c}\text { Mean value } \\
{[\mathrm{kN}]}\end{array}$ & $\begin{array}{c}\text { Standard deviation } \\
{[\mathrm{kN}]}\end{array}$ & $\begin{array}{c}\text { Variance } \\
{\left[\mathrm{kN}^{2}\right]}\end{array}$ \\
1 & 13.04 & & & \\
2 & 14.16 & 13.05 & 0.902 & 0.814 \\
3 & 11.95 & & & \\
\hline
\end{tabular}

Table 2: Debonding force values. 


\section{CONCLUSIONS}

A new experimental setup for investigating the mode II fracture behavior of FRP-concrete composite structures was proposed in this paper. The presented approach allows to model the interface behavior between the adherends via interest.

The experimental methodology was validated within experimental tests on debonding failure of concrete blocks reinforced with GFRP pultruded laminate, carried out at the Design Machine Laboratory of the University of Salerno.

Results of a preliminary test were presented and discussed in detail. The DIC method allows to provide with the full field displacement measurement, overcoming the limits of the conventional acquiring by LVDT or laser measurement devices. This non-contact optical technique has also allowed to evaluate the strain field with a good accuracy.

The proposed test methodology can be easily extended in a near future to the analysis of long-term behavior of adhesive interface, accounting its viscous nature [34-39], against a limited computational and time burden due to the optimized use of DIC technique.

\section{REFERENCES}

[1] Citarella, R., Cricrì, G., (2014). Three-dimensional BEM and FEM submodelling in a cracked FML full scale aeronautic panel, Applied Composite Materials, 21(3), pp. 557-577.

[2] Corato, V., Affinito, L., Anemona, A., Besi Vetrella, U., della Corte, A., Di Zenobio, A., Fiamozzi Zignani, C., Freda, R., Messina, G., Muzzi, L., Perrella, M., Reccia, L., Tomassetti, G., Turtù, S., (2015). Detailed design of the large-bore 8T superconducting magnet for the NAFASSY test facility, Superconductor Science and Technology, 28(3), article No 034005 .

[3] Ascione, L., Berardi, V.P., Feo, L., Mancusi, G., (2005). A numerical evaluation of the inter-laminar stress state in externally FRP plated RC beams, Composites Part B: Engineering, 36(1), pp. 83-90.

[4] Ascione, L., Berardi, V.P., Di Nardo, E., Feo, L., Mancusi, G., (2005). An experimental and numerical investigation on the plating of reinforced concrete beams with FRP laminates, Lecture Notes in Applied and Computational Mechanics, 23, pp. 303-314.

[5] Marfia, S., Sacco, E., Toti, J., (2010). An approach for the modeling of interface-body coupled nonlocal damage, Frattura ed Integrità Strutturale, 12, pp. 13-20.

[6] Marfia, S., Sacco, E., Toti, J., (2011). A coupled interface-body nonlocal damage model for the analysis of FRP strengthening detachment from cohesive material, Frattura ed Integrità Strutturale, 18, pp. 23-33.

[7] Ronagh, H.R., Eslami, A., (2013). Flexural retrofitting of RC buildings using GFRP/CFRP - A comparative study, Composites Part B: Engineering, 46, pp. 188-196.

[8] Bennati, S., Dardano, N., Valvo, P.S., (2012). A mechanical model for FRP-strengthened beams in bending, Frattura ed Integrità Strutturale, 22, pp. 39-55.

[9] D’Ambrisi, A., Mezzi, M., Feo, L., Berardi, V.P., (2014). Analysis of masonry structures strengthened with polymeric net reinforced cementitious matrix materials, Composite Structures, 113(1), pp. 264-271.

[10] Shardakov, I.N., Shestakov, A.P., Bykov, A.A., (2016). Delamination of carbon-fiber strengthening layer from concrete beam during deformation (infrared thermography), Frattura ed Integrità Strutturale, 38, pp. 331-338.

[11] De Piano, M., Modano, M., Benzoni, G., Berardi, V.P., Fraternali, F., (2017). A numerical approach to the mechanical modeling of masonry vaults under seismic loading, Ingegneria Sismica, 34(4), pp. 103-119.

[12] Berardi, V.P., De Piano, M., Teodosio, G., Penna, R., Feo, L., (2017), Advanced numerical models for the analysis of unreinforced and strengthened masonry vaults, in COMPDYN 2017 - Proceedings of the 6th International Conference on Computational Methods in Structural Dynamics and Earthquake Engineering, 2, pp. 5056-5069.

[13] American Concrete Institute (ACI), (2017). Guide for the design and construction of externally bonded FRP systems for strengthening concrete structures, ACI440.2R-17, Farmington Hills, MI.

[14] Fédération Internationale du Béton (FIB), (2001). Technical report on the "Design and use of externally bonded fibre reinforced polymer reinforcement (FRP EBR) for reinforced concrete structures", 1-138, ISBN 2-88394-054-1.

[15] National Research Council of Italy, (2013). Guide for the Design and Construction of Externally Bonded FRP Systems for Strengthening Existing Structures - CNR-DT 200R1-2013. Advisory Committee on Technical Regulations for Constructions, Rome. 
[16] Lepore, M.A., Perrella, M., (2017). From test data to FE code: A straightforward strategy for modelling the structural bonding interface, Frattura ed Integrità Strutturale, 11(39), pp. 191-201.

[17] Perrella, M., Berardi, V.P., Cricri, G., (2017). Mode II fracture behaviour of adhesively bonded reinforcements, in AIMETA 2017 - Proceedings of the 23rd Conference of the Italian Association of Theoretical and Applied Mechanics, 2, pp. 1824-1832.

[18] Perrella, M., Berardi, V.P., Cricrì, G., (2018). A novel methodology for shear cohesive law identification of bonded reinforcements, Composites Part B: Engineering, 144, pp. 126-133.

[19] Orefice, A., Mancusi, G., Berardi, V.P., Feo, L., Zuccaro, G., (2018). Residual stiffness of bonded joints for fibrereinforced polymer profiles, Composites Part B: Engineering, 144, pp. 237-253.

[20] Cricrì, G., (2018). Cohesive law identification of adhesive layers subject to shear load - An exact inverse solution, International Journal of Solids and Structures, 12, pp. 492-498.

[21] Mazzotti, A., Savoia, M., Ferracuti, B., (2009). A new single-shear set-up for stable debonding of FRP-concrete joints, Construction and Building Materials, 23, pp. 1529-1537.

[22] Bencardino, F., Condello, A., Ashour, A.F., (2017), Single-lap shear bond tests on Steel Reinforced Geopolymeric Matrix-concrete joints, Composites Part B: Engineering, 110, pp. 62-71.

[23] De Santis, S., Ceroni, F., de Felice, G., Fagone, M., Ghiassi, B., Kwiecień, A., Lignola, G.P., Morganti, M., Santandrea, M., Valluzzi, M.R., Viskovic. A., (2017). Round Robin Test on tensile and bond behaviour of Steel Reinforced Grout systems, Composites Part B: Engineering, 127, pp. 100-120.

[24] Ali-Ahmad, M., Subramaniam, K., Ghosn, M., (2006). Experimental investigation and fracture analysis of debonding between concrete and FRP sheets, Journal of Engineering Mechanics, 132(9), pp. 914-923.

[25] Carloni, C., Subramaniam, K.V., (2010). Direct determination of cohesive stress transfer during debonding of FRP from concrete, Composite Structures, 93(1), pp. 184-192.

[26] Carozzi, F.G., Colombi, P., Poggi, C., (2015). Calibration of end-debonding strength model for FRP-reinforced masonry, Composite Structures, 120, pp. 366-377.

[27] Napoli, A., de Felice, G., De Santis, S., Realfonzo, R., (2016). Bond behaviour of Steel Reinforced Polymer strengthening systems, Composite Structures, 152, pp. 499-515.

[28] Carloni, A., Santandrea, M., Imohamed, I.A.O., (2017). Determination of the interfacial properties of SRP strips bonded to concrete and comparison between single-lap and notched beam tests, Engineering Fracture Mechanics, 186, pp. 80104.

[29] Pohoryles, D.A., Melo, J., Rossetto, T., Fabian, M., McCague, C., Stavrianaki, K., Lishman, B., Sargeant, B., (2017). Use of DIC and AE for Monitoring Effective Strain and Debonding in FRP and FRCM-Retrofitted RC Beams, Journal of Composites for Construction, 21(1).

[30] Ghorbani, M., Mostofinejad, D., Hosseini, A., (2017). Bond Behavior of CFRP Sheets Attached to Concrete through EBR and EBROG Joints Subject to Mixed-Mode I/II Loading, Journal of Composites for Construction, 21(5).

[31] Bilotta, A., Ceroni, F., Lignola, G.P., Prota, A., (2017). Use of DIC technique for investigating the behaviour of FRCM materials for strengthening masonry elements, Composites Part B: Engineering, 129, pp. 251-270.

[32] Tekieli, M., De Santis, S., de Felice, G., Kwiecien', A., Roscini, F., (2017). Application of Digital Image Correlation to composite reinforcements testing, Composite Structures, 160, pp. 670-688.

[33] Babler, J., Adair, B., Antoniou, A., (2015). Ncorr: Open-Source 2d Digital Image Correlation Matlab Software, Experimental Mechanics, 55, pp. 1105-1122.

[34] Calì, C., Cricrì, G., Perrella, M., (2010). An Advanced Creep Model for Hardening and Damage Effects, Strain, 46, pp. 347-357.

[35] Ascione, L., Berardi, V.P., D’Aponte, A., (2011). A viscoelastic constitutive law for FRP materials, International Journal of Computational Methods in Engineering Science and Mechanics, 12(5), pp. 225-232.

[36] Ascione, L., Berardi, V.P., D’Aponte, A., (2012). Creep phenomena in FRP materials, Mechanics Research Communications, 43, pp. 15-21.

[37] Mancusi, G., Spadea, S., Berardi, V.P., (2013). Experimental analysis on the time-dependent bonding of FRP laminates under sustained loads, Composites Part B: Engineering, 46, pp. 116-122.

[38] Berardi, V.P., Perrella, M., Feo, L., Cricrì, G., (2017). Creep behavior of GFRP laminates and their phases: Experimental investigation and analytical modelling, Composites Part B: Engineering, 122, pp. 136-144.

[39] Berardi, V.P., Feo, L., Mancusi, G., De Piano, M., (2018). Influence of reinforcement viscous properties on reliability of existing structures strengthened with externally bonded composites, Composite Structures, 200, pp. 532-539. 